\title{
Multinationals and Transparency in Foreign Direct Liability Cases
}

\author{
The Prospects for Obtaining Evidence under the Dutch Civil Procedural Regime on the \\ Production of Exhibits
}

Liesbeth F.H. Enneking*

\section{Introduction}

On 30 January 2013, the The Hague district court rendered a final judgment with respect to a number of civil liability claims against Royal Dutch Shell (RDS) and its Nigerian subsidiary Shell Petroleum Development Company of Nigeria (SPDC) that had been pursued by four Nigerian farmers and the Dutch NGO Milieudefensie in relation to various oil spills from SPDC-operated pipelines in the Nigerian Niger Delta. ${ }^{1}$ This case, including the January 2013 ruling by the The Hague district court, is interesting for a number of reasons. ${ }^{2}$ One of them is that it forms part of a broader, worldwide trend towards similar civil liability procedures that has come up over the past two decades in Western societies around the world. Increasingly, transnational civil liability claims are being brought against parent companies of multinational corporations before courts in their Western society home countries in relation to harm caused to people and planet in (mostly developing) host countries as a result of these corporate groups' local activities there. ${ }^{3}$

The worldwide trend towards these so-called 'foreign direct liability cases' arises against the background of increasingly fierce socio-political debates on international corporate social responsibility and accountability that are taking place in Western societies around the world. In a globalizing world, where corporate activities are less and less confined to the territory of a single state but where an effective regulatory regime for internationally

* Liesbeth Enneking is a Postdoctoral Research Fellow at UCALL, Utrecht University's multidisciplinary Centre for Accountability and Liability Law, and an Assistant Professor of Private International Law at Utrecht University's Molengraaff Institute for Private Law. The author would like to thank prof. I. Giesen for comments on an earlier version of this article.

1. The Hague District Court, 30 January 2013, LJN BY9845 (re oil spill near Goi); The Hague District Court, 30 January 2013, LJN BY9850 (re oil spill near Oruma); The Hague District Court, 30 January 2013, LJN BY9854 (re oil spills near Ikot Ada Udo)

2. See, in more detail: Enneking 2014 (forthcoming).

3. See, for a detailed study of the contemporary socio-legal trend towards foreign direct liability cases: Enneking 2012. operating business enterprises and their transnational activities is lacking, questions arise as to the responsibilities of these corporate actors in relation to the potentially detrimental impacts of their activities on people and planet in host countries. These questions are particularly pertinent when it comes to these corporate actors' activities in host countries where environmental, health and safety, labour, and human rights standards are much less strict (or much less strictly enforced) than in the developed home countries where they are based. ${ }^{4}$ One of the most important international developments in this context over the past few years has been the development by UN Special Representative John Ruggie of an authoritative policy framework on business and human rights. This 'Protect, Respect and Remedy' framework ${ }^{5}$ and its accompanying Guiding Principles, ${ }^{6}$ which have found broad support by states, business enterprises, international organizations and NGOs around the world, seek to provide some clarity on the existence and delineation of state obligations and corporate responsibilities when it comes to preventing, mitigating and/or remedying the detrimental impacts that corporate activities may have on the human rights of others. ${ }^{7}$ The framework's third pillar emphasizes the significance of allowing and enabling victims of corporate human rights abuse to seek redress for their detriment through both non-judicial and judicial mechanisms, and the Guiding Principles urge states to

[...] take appropriate steps to ensure the effectiveness of domestic judicial mechanisms when addressing business-related human rights abuses, including considering ways to reduce legal, practical and other relevant barriers that could lead to a denial of access to remedy. ${ }^{8}$

Legal barriers that may prevent legitimate cases of corporate human rights abuse from being addressed

4. See, in more detail: Enneking 2012, pp. 363-441.

5. "Protect, Respect and Remedy: A Framework for Business and Human Rights", A/HRC/8/5 (7 April 2008).

6. "Guiding Principles on Business and Human Rights: Implementing the United Nations 'Protect, Respect and Remedy' Framework", A/HRC/ 17/31 (21 March 2011) (hereinafter: Guiding Principles).

7. See, in more detail: Enneking 2012, pp. 425-440.

8. $\quad$ Guiding Principles, principle 26. 
through judicial mechanisms may arise, for example, where domestic criminal and civil laws allow corporate groups to avoid legal accountability through the attribution of legal responsibility among members of the group and where claimants who face a denial of justice in the host state are unable, regardless of the merits of their claims, to gain access to home state courts. Examples of practical and procedural barriers include the costs of bringing claims, difficulties for the claimants in securing legal representation, and inadequate options for aggregating claims or enabling representative proceedings. ${ }^{9}$ According to the Guiding Principles:

Many of these barriers are the result of, or compounded by, the frequent imbalances between the parties to business-related human rights claims, such as in their financial resources, access to information and expertise. $^{10}$

Indeed, one of the main characteristics of foreign direct liability cases is the inequality of arms that typically exists between the host country plaintiffs on the one hand and the corporate defendants on the other when it comes to financial scope, level of organization and access to relevant information. Plaintiffs in these cases are typically hampered by a structural lack of transparency as regards both the group and operational structures of the multinationals involved and the facts and circumstances that have caused them to suffer harm. As a consequence, the procedural rules pertaining to the collection of evidence that apply in the forum countries in which they are pursued typically play an important part in these cases. This also means that in countries where the prospects for obtaining evidence in civil procedures are poor, this may add a potentially crucial procedural barrier for host country plaintiffs seeking to pursue foreign direct liability claims that may be difficult to overcome. The main question to be answered in this article is what the prospects are for plaintiffs in Dutch foreign direct liability claims (i.e. foreign direct liability claims pursued before Dutch courts against multinational corporations that are based in the Netherlands) when it comes to obtaining evidence under the Dutch civil procedural regime on the production of exhibits. This question is highly relevant, since the course of the proceedings in the first and (so far) only Dutch foreign direct liability case (the Dutch Shell Nigeria case, which will be discussed further below) suggest that the Dutch procedural regime on the collection of evidence may pose a significant hurdle for plaintiffs seeking to pursue foreign direct liability claims before Dutch courts. In order to answer it, this article will start with a more detailed discussion of the contemporary trend towards foreign

9. Guiding Principles, principle 26, commentary. With respect to the costs of bringing claims, it is added in the Commentary that those may be considered to present a barrier to accessing judicial remedy where those costs " [...] go beyond being an appropriate deterrent to unmeritorious cases and/or cannot be reduced to reasonable levels through Government support, 'market-based' mechanisms (such as litigation insurance and legal fee structures), or other means."

10. Guiding Principles, principle 26, commentary. direct liability cases (2), followed by a discussion of the role that transparency plays in this context (3) and of the significance in this context of rules on evidence and proof (4).

Subsequently, an outline will be provided of the Dutch civil procedural regime on the production of exhibits (5), as well as some legal comparative reflections on this matter with a focus in particular on US rules on the collection of evidence (6) as, due in part to the plaintifffriendly US litigation culture, the far majority of foreign direct have so far been pursued before US federal and state courts. ${ }^{11}$ This will be followed by a discussion of the extent to which the Dutch civil procedural regime on production of exhibits poses structural impediments to plaintiffs in Dutch foreign direct liability cases (7) and conclusion that includes some reflections on possible improvements in this context (8).

\section{Foreign Direct Liability}

The socio-legal trend towards foreign direct liability cases that Western societies have been witnessing over the past two decades started out in the United States in the mid-1990s, where it gained momentum as a result of the 'rediscovery' some ten years earlier of a somewhat obscure US federal statute, the Alien Tort Statute (ATS). ${ }^{12}$ This 1789 statute, which had lain dormant for 200 years, turned out to provide a much-needed accountability mechanism for victims of international human rights violations perpetrated anywhere in the world, enabling them to address and seek redress for their detriment through civil liability claims brought before US federal courts against those directly or indirectly responsible. Although initially mainly used as a basis for civil claims against individual perpetrators of international human rights violations or international crimes, like Karadzic and Marcos, from the mid-1990s onwards the statute also became used as a basis for civil claims against corporate actors. ${ }^{13}$

Since then, around 150 foreign direct liability claims have been pursued before US federal courts on the basis of the ATS. ${ }^{14}$ Well-known are the claims against a score of multinationals including IBM, Ford and General Motors for their alleged involvement in the human rights violations perpetrated by the South African Apartheid regime. Other well-known examples are the claims against Shell for its alleged involvement in human rights violations perpetrated by the Nigerian

11. See, for instance: Enneking 2012, pp. 117-121.

12. 28 United States Code $\$ 1350$. This statute, which has famously been referred to as a 'legal Lohengrin', since "no one seems to know whence it came" (or, more particularly: what exactly the 1789 framers had in mind when they enacted it), provides: "The district courts shall have original jurisdiction of any civil action by an alien for a tort only, committed in violation of the law of nations or a treaty of the United States". See for quote: IIT v. Vencap, Ltd., 519 F.2d 1001 (2nd Cir. 1975) (Friendly, J., at 1015).

13. See, in more detail, e.g. Enneking 2012, pp. 77-87, 277-278.

14. See, for instance: Drimmer \& Lamoree 2011, p. 465. 
military government against environmental activists who were protesting against the environmental degradation caused by oil-extraction activities in the Ogoniland region of the Niger Delta. ${ }^{15}$ One of these claims against Shell was settled out of court in June 2009 for 15.5 million US dollars; the remaining claim, however, recently led to a controversial ruling by the US Supreme Court, which seems to have significantly limited the prospects for future ATS-based foreign direct liability cases. ${ }^{16}$

Still, the socio-legal trend towards foreign direct liability cases has not remained confined to US federal courts as a venue, nor to the ATS as a legal basis, as it has spread over the past two decades also to US state courts and to courts in other Western societies such as Canada, Australia and the United Kingdom. Slowly but certainly, more and more claims similar to those brought before US federal courts have started to become pursued also elsewhere against locally established corporate actors accused of having caused harm to people and planet abroad. In the absence of a specific statute such as the ATS, these claims have typically been based on general principles of tort law and the tort of negligence in particular. ${ }^{17}$ Recent examples include the civil claims pursued before the London High Court against Trafigura for its involvement in the Probo Koala toxic waste dumping incident in the Ivory Coast, ${ }^{18}$ and the civil liability procedure that was filed before a French court in 2007 by French NGOs against two French companies for their role in the alleged illegal construction of a light rail system between Jerusalem and the occupied West Bank in Israel. ${ }^{19}$

The Dutch Shell Nigeria case, which was initiated in late 2008/early 2009 and consisted of a number of claims brought in relation to oil spill incidents near three Nigerian villages, was the first foreign direct liability case to be brought before a Dutch court. According to the plaintiffs, the Nigerian subsidiary had not exercised due care in preventing the oil spills from occurring, in mitigating their consequences and in properly cleaning up the contaminated sites afterwards, whereas the parent company had failed to use its influence over the group's environmental policies to ensure that the local oil-extraction activities engaged in by its Nigerian subsidiary were undertaken with due care for

15. See, for details and further references on these two cases (and on a large number of other, similar, cases), the website of the Business \& Human Rights Resource Centre. Available at: <www.business-humanrights.org/Categories/Lawlawsuits/Lawsuitsregulatoryaction/LawsuitsSelectedcases>.

16. Kiobel v. Royal Dutch Petroleum (No. 10-1491), 569 US _ (2013). See, in more detail, for instance: Enneking 2014 (forthcoming).

17. See, in more detail: Enneking 2012, pp. 87-91.

18. See, for details and further references on this case, the website of the Business \& Human Rights Resource Centre. Available at: <www.business-humanrights.org/Categories/Lawlawsuits/Lawsuitsregulatoryaction/LawsuitsSelectedcases/TrafiguralawsuitsreCtedlvoire>

19. The companies were alleged to have contributed to the violation of several international law provisions, including those incorporated in the Fourth Geneva Convention and the Hague Convention of 1954 for the Protection of Cultural Property in the Event of Armed Conflict; the court held that the instruments in question contain obligations for the state parties only. See, for more details: Maes 2013. people and planet locally. The plaintiffs asked the court, among other things, for a declaratory judgment holding that the defendant companies had acted unlawfully towards them and were jointly and severally liable for the resulting damage, and for injunctions ordering the defendants to carry out overdue maintenance to the pipelines, to complete sanitation of the lands and fishponds affected by the oil spills in dispute, and to draw up contingency plans that would allow for a more adequate response to future oil spills. ${ }^{20}$

In its final ruling in January 2013, the The Hague district court, on the basis of the evidence presented to it, came to the conclusion that the oil spills were a result of sabotage, and not a result of faulty maintenance as had been argued by the plaintiffs. This, in combination with the fact that under Nigerian law the operator of an oil pipeline is not liable, in principle, for harm resulting from oil spills caused by sabotage, led the court to dismiss the majority of the claims against the Nigerian Shell subsidiary SPDC. ${ }^{21}$ It also dismissed all of the claims against the parent company RDS, finding that under Nigerian tort law a parent company does not in principle have a legal obligation to prevent its subsidiaries from causing harm to third parties except under special circumstances, which the court did not find to exist. ${ }^{22}$ Still, the court did not send the plaintiffs home empty-handed altogether, as it did grant their claims against SPDC in one of the procedures, which related to two oil spills in 2006 and 2007 from an abandoned wellhead near the village of Ikot Ada Udo, ordering SPDC to pay compensation for the resulting loss. ${ }^{23}$

\section{Foreign Direct Liability and Transparency}

What makes the contemporary trend towards foreign direct liability cases particularly significant is the fact that through these cases, Western society systems of tort

20. See the court documents, some of which have been translated in English, on the Milieudefensie website. Available at: <www.milieudefensie.nl/english/shell/oil-leaks/courtcase/press>. See also Enneking 2012, pp. 104-107 and Enneking 2014 (forthcoming).

21. The Hague District Court, 30 January 2013, LJN BY9845 (oil spill near Goi), paras. 4.43-4.58; The Hague District Court, 30 January 2013, LJN BY9850 (oil spill near Oruma), paras. 4.45-4.60.

22. The Hague District Court, 30 January 2013, LJN BY9845 (oil spill near Goi), paras. 4.30-4.39; The Hague District Court, 30 January 2013, LJN BY9850 (oil spill near Oruma), paras. 4.32-4.41; The Hague District Court, 30 January 2013, LJN BY9854 (oil spills near Ikot Ada Udo), paras. 4.26-4.34

23. The Hague District Court, 30 January 2013, LJN BY9854 (re oil spills near Ikot Ada Udo), paras. 4.38-4.46. Although starting, also here, from the assumption that the immediate cause of the oil spills had been sabotage, the court in this specific case decided that SPDC was liable for the damage caused to the plaintiff's crops and fishponds as a result of the oil spills. According to the court, SPDC had been negligent in leaving behind the wellhead without adequately securing it, thus making it simple for saboteurs to unscrew its valves. This led the court to conclude that in failing to take sufficient precautions against the risk of sabotage, SPDC had violated the duty of care it owed to the neighbouring farmers. 
law are given a role in promoting international corporate social responsibility and accountability, in a number of ways. $^{24}$

First of all, these cases provide host country citizens who have suffered harm as a result of the activities of multinational corporations with a way to address and obtain redress for their detriment even if local remedies are inadequate. Furthermore, they provide multinational corporations with behavioural incentives to operate in a socially responsible manner, not only at home but also abroad. In addition, they explore the hard law edges of the predominantly soft law norms on the responsibilities of internationally operating business enterprises for the direct and indirect consequences of their activities on people and planet abroad and provide some guidance, albeit in retrospect and with a focus on the particular circumstances of each case, with respect to the level of care these corporate actors are supposed to exercise in this respect.

Lastly, and most importantly in the context of this article, these cases provide a measure of transparency as regards the potentially detrimental effects that the transnational activities of 'our' multinational corporations may have on people and planet elsewhere. They do so in two ways. On the one hand, they provide the host country victims involved with a better understanding of the facts and circumstances leading up to their detriment and of the extent to which the corporate actors involved are to blame for it. On the other hand, they contribute in a broader sense to a more complete picture in Western societies on the way in which 'their' multinationals operate in host countries, and on the harmful effects that those operations may have on people and planet there. ${ }^{25}$

Of course, the role that Western society systems of tort law may play in this context is closely connected to the legal feasibility of these cases, which in the end is determined by four main factors. First of all, there is the question whether the court involved has jurisdiction over the transnational tort claim brought before it. Secondly, there is the issue of the applicable system of tort law on the basis of which the claim is to be decided. Thirdly, there are the conditions for liability that are connected to the substantive legal basis upon which the claim is brought. And fourthly, the feasibility of these claims is determined to a large extent by the procedural and practical conditions of the forum country. The effects of these factors obviously range according to the circumstances of the case, the nature and set-up of the claim, and the legal system of the country in which it is brought. Where it comes to procedural and practical circumstances in the forum country, for instance, it is a

24. See, for a detailed discussion of the different roles that Western society systems of tort law may play in this context, including through the creation of transparency on the potential detrimental impacts of the transnational activities of internationally operating business enterprises: Enneking 2012.

25. See, for a more general discussion of the role of transparency in contemporary debates on international corporate social responsibility and accountability: Kerr et al. 2009, pp. 241-284. well-known fact that the United States features a particularly plaintiff-friendly litigation culture, whereas across the Atlantic, in continental Europe, procedural and practical circumstances are far less likely in comparison to be conducive to the successful pursuit of this type of litigation. $^{26}$

In the Netherlands, the two main stumbling blocks that host country plaintiffs are likely to be faced with when seeking to bring their foreign direct liability claims before Dutch courts are the costs of litigating, combined with the limited possibilities to bring collective actions, and the fact that the Dutch system of evidence gathering in civil procedures is relatively restrictive. ${ }^{27}$ With respect to the litigation costs/collective actions threshold, interesting developments are taking place both in the Netherlands, where the Netherlands Bar Association is experimenting with a partial removal (in personal injury cases) of the ban on result-oriented lawyers' fees, ${ }^{28}$ and at the EU-level, where the European Commission has recently set out a number of common nonbinding principles for collective redress mechanisms meant to ensure access to justice before EU Member State courts. ${ }^{29}$ Combined, these developments suggest a threshold as regards litigation costs/collective actions that potentially may become lower for future plaintiffs seeking to bring foreign direct liability claims before Dutch courts.

The evidence threshold, on the other hand, is likely to remain a serious impediment for plaintiffs in future Dutch foreign direct liability cases, despite the fact that the Dutch provision on the obligation to provide exhibits, Article 843a of the Dutch Code of Civil Procedure (DCCP) (which will be discussed in more detail below), is currently under revision. This seems to be confirmed by the Dutch Shell Nigeria case, where the The Hague district court in an interlocutory ruling in September 2011 (which will be discussed further in section 7 below) dismissed a request made by the plaintiffs for Shell to provide exhibits of certain key evidentiary documents pertaining to, for instance, the condition of the oil pipelines involved and the Shell group's internal policies and operational practices. ${ }^{30}$ This ruling evidences the relatively restrictive Dutch approach to discovery and disclosure of documents. It dealt a painful blow to the plaintiffs, who had hoped to be able to use the requested documents to further substantiate their claims that the oil spills in dispute were a result of faulty main-

26. See, for a more detailed discussion: Enneking 2012, pp. 187-202

27. See, for a more detailed discussion: Enneking 2012 pp. 256-265, 352-356.

28. See, for more information, the Dutch Bar Association website: "No cure no pay - Factsheet experiment resultaatgerichte belonging". Available at: <www.advocatenorde.nl/3282/advocaten/no-cure-no-pay.html? thema=thema/toegang-tot-het-recht\&themalD $=2737$ > .

29. See, for more information, the European Commission website: “Commission recommends Member States to have collective redress mechanisms in place to ensure access to justice" (11 June 2013). Available at: <http://ec.europa.eu/justice/newsroom/civil/news/130611_en.htm>.

30. The Hague District Court, 14 September 2011, LJN BU3529 (re oil spills near Ikot Ada Udo); The Hague District Court, 14 September 2011, LJN BU3535 (re oil spill near Oruma); The Hague District Court, 14 September 2011, LJN BU3538 (re oil spill near Goi). 
tenance rather than sabotage (as had been claimed by the defendants) and that both parent company RDS and subsidiary SPDC had violated their respective duties of care owed to the plaintiffs in not preventing the oil spills from occurring. ${ }^{31}$

Their inability to do so undoubtedly significantly hampered their chances of convincing the court that both the subsidiary and the parent company could and should have done more to prevent the oil spills from occurring and/or to mitigate their harmful consequences. After all, the court's assumption that the oil spills were a result of sabotage rather than faulty maintenance prevented it from even considering that the parent company could have a duty of care towards the Nigerian plaintiffs, as the requisite 'proximity' factor could not be satisfied. It also led it to dismiss most of the claims against the subsidiary, in view of the fact that under Nigerian law the operator of an oil pipeline is not liable, in principle, for harm resulting from oil spills caused by sabotage. This suggests that the outcome might have been different if the plaintiffs would have been able to get access to the requested documents (provided, of course, those would have allowed them to sufficiently substantiate their claims). Interestingly, the plaintiffs may get another opportunity to try and convince a court to grant them the right to inspect the documents requested, as the The Hague district court's January 2013 decision has been appealed by both parties, meaning that the case will be reconsidered, in its entirety, by the The Hague Court of Appeals. ${ }^{32}$

\section{Evidence, Proof and Establishing the 'Truth' in Dutch Civil Procedures}

One of the basic rules of civil procedure not only in the Netherlands but also elsewhere is that the party that initiates a civil claim is in principle the one to prove the facts and circumstances substantiating that claim. ${ }^{33}$ Accordingly, the burden of proof in foreign direct liability cases, regardless of where they are pursued, will generally be on the host country plaintiffs bringing these claims. It must be noted, however, that in the Netherlands, as in most other legal systems, there are a number of exceptions to this general rule, including the possibility of a reversal of the burden of proof under special circumstances, the possibility of the imposition of an aggravated burden on the defendant to motivate his defence, and the possibility of a more generous appreciation of the available evidence by the court, for instance

31. See also Enneking 2012, pp. 259-262.

32. See, for instance: "Milieudefensie surprised by Shell's appeal against Nigerian victim", Milieudefensie website. Available at: <www.milieu defensie.nl/english/pressreleases/milieudefensie-surprised-byshell2019s-appeal-against-nigerian-victim>.

33. See, for instance, Arts. 149 and 150 of the Dutch Code of Civil Procedure (hereinafter: DCCP). through presumptions of fact. ${ }^{34}$ In transnational noncontractual liability cases brought before Dutch courts, matters such as these tend to fall within the scope of the law applicable to the case and are as such not automatically governed by Dutch law as the law of the forum country (meaning that they also fall outside the limited scope of this contribution). ${ }^{35}$

Rules pertaining to the collection of evidence and modes of proof, on the other hand, do tend to be considered as rules of procedure and not as rules of material tort law, at least in the Netherlands, and are as such governed by Dutch law as the law of the forum country in transnational non-contractual liability cases brought before Dutch courts. ${ }^{36}$ Unlike in criminal procedures, there are few restrictions on the modes of proof that parties in a civil procedure before a Dutch court may seek to rely on in order to substantiate their claims; ${ }^{37}$ the assessment of the evidence furnished is in principle left to the court's discretion. ${ }^{38}$ At the same time, however, the means to discover relevant facts and circumstances that the parties to a civil dispute have at their disposal are far more limited than those that public prosecutors, backed up by public investigation departments entrusted with broad public entitlements, can avail themselves of in a criminal procedure. Although Dutch civil procedural law provides a number of instruments that the parties to a civil dispute may rely on to obtain relevant information from their opponents or from third parties, their options for collecting evidence necessarily remain relatively limited. Although ideally, from the perspective of fairness at least, both parties in a civil procedure should have the same information at their disposal as regards the issue in dispute, in practice this will often not be the case. A minimum threshold in this respect is provided by the right to a fair trial as laid down in Article 6 of the European Convention on Human Rights, which applies to any civil (or criminal) procedure initiated before a Dutch court, regardless of whether it is a purely domestic procedure or whether the procedure has internation-

34. See, in more detail on the obligation to furnish facts and the burden of proof in Dutch civil procedural law, for instance: Snijders et al. 2007, pp. 215-229. See also, from a comparative perspective: Giesen 2001.

35. See Art. 21(1) of Regulation (EC) No. 864/2007 of the European Parliament and of the Council of 11 July 2007 on the law applicable to noncontractual obligations (Rome II), OJ L199/40, 31 July 2007: “The law governing a non-contractual obligation under this Regulation shall apply to the extent that, in matters of noncontractual obligations, it contains rules which raise presumptions of law or determine the burden of proof." Compare also Art. 10:13 of the Dutch Civil Code: "The law that is governing a legal relationship or legal fact, shall apply also to the extent that it constitutes legal presumptions with respect to that legal relationship or legal fact, or contains rules for the distribution of the burden of proof."

36. Compare Art. 10:3 of the Dutch Civil Code (hereinafter: DCC): "Dutch law shall apply to the conduct and procedure of legal proceedings in Dutch courts."

37. See Art. 152(1) DCCP, which expressly states that all forms of evidence are admissible. The main modes of proof that are mentioned in the Dutch Code of Civil Procedure include not only documents, deeds and judgments, but also witness statements, expert statements and judicial site visits. See Arts. 156-160, 163-185, 193-200 and 201 of the Dutch Code of Civil Procedure, respectively.

38. See Art. 152(2) DCCP. 
al aspects. ${ }^{39}$ One of the main aspects of this right to a fair trial is the principle of 'equality of arms' between the parties to a legal dispute. According to the European Court of Human Rights (ECHR),

[...] each party must be afforded a reasonable opportunity to present his case - including his evidence under conditions that do not place him at a substantial disadvantage vis-à-vis his opponent. ${ }^{40}$

It should be noted, however, that the ECHR Member States are left with a margin of appreciation as to how to achieve this result, which means that not all limitations to the equality of arms principle are automatically incompatible with the Convention.

Apart from the importance of ensuring a certain measure of informational equality between the parties to a civil dispute in order to allow for a fair trial, transparency in the sense of uncovering the material truth also plays a broader, more public role in this context. After all, the legitimacy of a judgment is determined largely by the extent to which that judgment is based on true facts and actual circumstances. Judges are public authorities fulfilling a public role, a role that not only consists of enforcing existing laws and, by doing so, realizing the public objectives that those laws seek to bring about, but also of - where necessary - developing the law through decisions in individual disputes. The fact that judicial decision-making in civil procedures, which primarily revolve around the private interests of the private parties involved, also has a strong impact on broader, more public interests emphasizes the importance of transparency, in the sense of uncovering the material truth, also in these procedures. ${ }^{41}$

Closely related to this broader picture, a growing tendency has been perceived to exist in Dutch civil procedural law towards an increased emphasis on the importance of seeking and establishing the truth in civil procedures. $^{42}$ This tendency is reflected in the growing importance of statutory obligations on the parties to a civil dispute before a Dutch court to disclose information on relevant facts and circumstances related to their case. ${ }^{43}$ These obligations are the exception to the general rule of party autonomy, ${ }^{44}$ on the basis of which parties to a civil dispute are in principle free to determine whether and in what way (i.e. to what extent and on the basis of what facts, circumstances and legal grounds) they present their case to a court. ${ }^{45}$ In view of this tendency, the Dutch legislator has in 2002 codified an obli-

39. See, more generally, on the role that Art. 6 ECHR may play in foreign direct liability cases: Enneking 2012, pp. 199-202.

40. Dombo Beheer v. The Netherlands, ECHR (1993) 49 14448/88 (27 October 1993).

41. See, for a detailed discussion of the role of fact-finding and establishing the truth in Dutch civil procedural law: De Bock 2011. See also, more generally: Loth et al. 2012

42. See, for a detailed study of this tendency: De Bock 2011

43. See, for a detailed study of these statutory duties: Van Den Reek 1997 See also, more recently: De Bock 2011, pp. 51-63.

44. See Arts. 24 and 149 DCCP.

45. See, for instance: Wijnbergen 2011, pp. 974-980. gation to provide information in the DCCP, which requires the parties to a civil dispute to fully and truthfully disclose the facts and circumstances that are relevant for the judicial resolution of the dispute, including information that may be detrimental to the party adducing it. ${ }^{46}$

It is unclear to what extent this obligation to provide information, in combination with the fact that the court may under all circumstances and in any stage of the procedure require the parties to further substantiate their arguments or to produce relevant documents, ${ }^{47}$ goes in the direction of a general duty to disclose all relevant information as exists in Anglo-American law. Although opinions on this matter range, ${ }^{48}$ a general obligation on parties to disclose all documents that may be relevant for (the adjudication of) the dispute does not (yet) seem to exist in Dutch civil procedural law at this point. ${ }^{49}$ In case of failure to comply with these obligations in the absence of any compelling reasons to disregard them (such as the reasonable fear that confidential data become publicly known), the court may interpret the refusal to provide the information in question as it sees fit. $^{50}$

Although these obligations to provide information are primarily meant to assist the court in reaching a wellinformed decision and are as such not actionable for the parties to the dispute themselves, the principle of audi alteram partem (hearing both sides of the argument) brings with it that any information provided by one party to the dispute should also be made available to the other party. ${ }^{51}$ As such, they may provide the parties to the dispute with a stepping stone that may better enable them to invoke their right to request exhibits under Article 843a DCCP, which will be further discussed in the next section. ${ }^{52}$

46. See, in more detail: De Bock 2011, pp. 51-56. See also, for instance: HR 28 September 2001, NJ 2002, 104.

47. See, Art. 22 DCCP.

48. See, on the one hand, Sijmonsma 2010, who argues that there is no general duty for parties to a civil dispute to provide information relevant to the dispunte (p. 44), and, on the other hand, De Bock 2011, who has a much broader interpretation of this obligation to provide information in Dutch civil procedural law (pp. 52-56).

49. Similarly: Giesen 2001, pp. 17-24, 30-32

50. This may mean, for instance, that the court interprets the refusal to provide information to the detriment of the refusing party, is especially critical in its evaluation of the credibility of the arguments raised by that party, and/or increases the burden of proof resting on that party. See, for instance: Wijnbergen 2011. See also, HR 25 maart 2011, LJN BO9675, where the Supreme Court discusses, among other things, the question how a court should deal with a case in which not all of the relevant facts have been put forward by the parties.

51. See, for instance: Sijmonsma, 2010, pp. 54-55.

52. Similarly: Sijmonsma 2010, pp. 55-58. 


\section{The Dutch Civil Procedural Regime on the Production of Exhibits}

A potentially important tool for a plaintiff in a foreign direct liability case (or any other type of civil liability case, for that matter) seeking to furnish the court with sufficient evidence in order to substantiate his claims, is provided by the provision on document disclosure that is currently laid down in Article 843a DCCP. On the basis of this provision, a party to a civil dispute can file a motion requesting the disclosure by the other party to the dispute (or by a third party) of documentary evidence that the requesting party can use to substantiate his claims; the evidence requested on this basis may include not only text documents but also other types of data files, such as films, photos or CD-ROMs ${ }^{53}$ In the particular context of foreign direct liability cases, plaintiffs may for example seek disclosure not only of documents related to the proximate cause of the harm caused such as for instance technical reports, but also, for instance, documents that provide insight into internal group policies and command structures and/or due diligence reports mapping out the detrimental impacts that the transnational activities of the multinational group involved may have on people and planet elsewhere. ${ }^{54}$

The right to request disclosure of documents on the basis of Article 843a DCCP is by no means unlimited under Dutch civil procedural law; in order for a request to be granted, three conditions need to be satisfied. First of all, the requesting party must be able to show that it has a legitimate interest in (being able to inspect) the requested documents. The guiding principle in this respect is the question whether either of the parties would be unreasonably advantaged or would be unreasonably disadvantaged if the requested documents would not be made available as evidence in the procedure. With respect to some subject matter areas, legal provisions exist that specifically provide for a right to request disclosure, as is the case for instance with respect to the employee's right to require the disclosure of administrative records by his employer insofar as

53. See, for a detailed study of the obligation to provide exhibits (or: the right to request disclosure of documents) as laid down in Art. 843a DCCP: Ekelmans 2010. See also: Sijmonsma 2010.

54. As a result of the socio-political pressure emanating from the UN framework on Business and Human Rights and its accompanying Guiding Principles, which specifically require internationally operating business enterprises to conduct human rights due diligence, as well as from the increasing number of sectoral initiatives in the CSR-field, which more and more often tend to set out similar requirements, the prevalence and level of detail of such reports is rapidly increasing. See also, with further references: Lambooy 2010, pp. 330-331. those records relate to his wage level. ${ }^{55}$ In most cases, however, it is left up to the court to decide, on a caseby-case basis, whether the legitimate interestrequirement has been satisfied.

It is difficult to discern a clear direction in the case law when it comes to the interpretation of the legitimate interest-requirement of Article 843a DCCP; some courts tend to be less restrictive on this matter than others. What is clear, however, is that where the main action in a dispute is considered by the court to be unlikely to succeed, a request by the plaintiffs for exhibition of documents is also unlikely to be successful. ${ }^{56} \mathrm{It}$ is important to note in this respect that one of the main objectives of the legitimate interest-requirement is to prevent so-called 'fishing expeditions', that is, requests for all kinds of documents put forward without any clearly defined plan or purpose in the hope of discovering information that may somehow be used to substantiate a civil liability claim. The communis opinio among Dutch courts and policy-makers seems to be that such fishing expeditions represent an undesirable phenomenon closely connected to the equally abhorrent US-style 'claim culture' with excessive numbers of civil procedures, high litigation costs, and 'blackmail settlements'. ${ }^{57}$

The second condition that needs to be satisfied in order for a request for disclosure of documents on the basis of Article 843a DCCP to be granted is that the requesting party must be able to adequately specify the documents involved. Like the legitimate interest-requirement, this requirement is also meant to prevent fishing expeditions. $^{58}$ The guiding principle in this respect is that it should be sufficiently clear, in light of the particular claim put forward, which particular documents are requested, why these particular documents are relevant, and that an obligation to produce these specific documents would not go beyond what is strictly necessary to ensure a fair and equal procedure. ${ }^{59}$ Although not completely unambiguous, it seems that the prevailing opinion in both case law and literature is that it is not necessary for the requesting party to have prior knowledge of the contents of the requested documents. ${ }^{60}$

The third condition that needs to be satisfied for a successful request for disclosure of documents on the basis

55. See Art. 7:619(1) DCC, which provides: "If all or part of the remuneration has been made dependent on any data that must be obtained from the books, records or other data carriers of the employer, the employee has the right to require the employer to produce such documentary evidence as he needs in order to establish such data". See also, for instance, HR 6 October 2006, LJN AX7774, r.o. 3.3.2-3.3.3, where the Dutch Supreme Court considers that the existence of a specific statutory right to request disclosure as laid down in Art. 7:619 DCC satisfies the reasonable interest-requirement of Art. 843a DCCP in cases pertaining to the specific subject matter area covered by Art. 7:619 DCC.

56. See for instance, with further references to case law: Ekelmans 2010, pp. 87-95; Sijmonsma 2010, pp. 117-132.

57. See, for instance, with further references to case law and literature on this matter: Sijmonsma 2010, p. 118.

58. See, for instance: Sijmonsma 2010, p. 142.

59. See Sijmonsma 2010, p. 142

60. See, with further references to relevant case law: Sijmonsma 2010, pp. 141-148; Ekelmans 2010, pp. 95-100. 
of Article 843a DCCP is that the requesting party must be able to show that the documents are somehow connected to a legal relationship involving the requesting party itself or its legal predecessor. ${ }^{61}$ This includes for instance the legal relationship that comes into existence between the victim(s) and the perpetrator(s) of a wrongful act or omission. ${ }^{62}$ Some authors have supported the view that the legal relationship-requirement should be interpreted broadly, meaning that a party to a civil liability dispute should also be able to request the disclosure of documents that are needed to prove that such a wrongful act or omission has occurred (and, consequently, that a legal relationship between victim and perpetrator has come into existence)..$^{63}$

Even if all three conditions are satisfied, the party in possession of the requested documents may still refuse the disclosure of those documents if there are weighty reasons to do so, including for instance legal obligations or privacy-related or business-economical interests requiring that the information concerned is kept confidential. ${ }^{64}$ In practice, however, an appeal to such weighty reasons for non-disclosure is not easily granted; it is up to the party in possession of the requested documents to prove that the general interest of establishing the truth in civil procedures should in that particular case give way to the interest of confidentiality. ${ }^{65}$ The court's task is to weigh the competing interests against each other and, in doing so, to make sure that neither of the parties is given an unreasonable advantage or disadvantage as a result of the decision whether or not the requested documents are made available as evidence in the procedure. If the party in possession of the requested documents is ordered by the court to produce those documents but refuses to do so, the court draws from this any conclusions it may see fit; this may have repercussion not only for the burden of proof on the refusing party and the evaluation of his pleas, but may also lead the court to order the refusing party to pay costs, to impose a penalty, or even to commit for failure to comply with a judicial order. ${ }^{66}$

As regards the timing of a request for disclosure of documents, it should be noted that such a request can be filed not only as a motion in the course of a civil procedure while it is pending before a Dutch court, but also as a separate claim in furtherance of another procedure or of a future procedure. ${ }^{67}$ Recent case law by the Dutch Supreme Court makes clear that the latter option exists

61. It is generally assumed that it is not necessary for both parties to the dispute to be connected to said legal relationship, but that it suffices that at least one of them - the requesting party - is. See also Ekelmans 2011, p. 348.

62. See, for a more detailed discussion of the requirements that exist in this respect and references to relevant case law: Ekelmans 2010, pp. 87-100; Sijmonsma 2010, pp. 117-157.

63. See, with further references to relevant case law and literature: Sijmonsma 2010, pp. 148-157, 169-172.

64. Art. $843 \mathrm{a}(4)$

65. See, for instance: Ekelmans 2010, pp. 137-140.

66. See, in further detail and with references to relevant case law: Ekelmans 2010, pp. 215-222.

67. See, for instance: Sijmonsma 2010, p. 225; De Bock 2011, pp. 139-142. See also, for instance: HR 6 October 2006, LJN AX7774. even if the main procedure is pending abroad or is intended to be brought before a court outside the Netherlands. ${ }^{68}$ The significance of the option of filing a pretrial request for disclosure of documents is that it may allow potential plaintiffs to better assess their position, including the chances of successfully bringing suit and the question which private or legal person the claim should be directed at. This kind of strategic, pre-trial evidence gathering has specifically been endorsed by the Dutch Supreme Court in context of provisional witness statements. ${ }^{69}$ Despite the fact that various authors have speculated on its potential also in the context of requests for disclosure of documents, ${ }^{70}$ it has so far remained little used in this latter context (and has not been explored in the particular context of foreign direct liability cases), something that may partly be explained by the fact that the possibilities for gathering evidence offered by Article 843 a DCCP have only started to be explored since the late $1990 \mathrm{~s}^{71}$

\section{Comparative Reflections}

Notwithstanding the obvious advantages that it may under certain circumstances entail for plaintiffs seeking to obtain documentary evidence that is not in their possession, the Dutch civil procedural regime on document disclosure is much more restrictive than for instance its US counterpart of pre-trial discovery. This has raised questions as to why these differences exist and to what extent the (Anglo-)American rules on the gathering of evidence in civil procedures may serve as an example of possible ways in which the Dutch regime could be liberalized. It should be noted at the outset, however, that because of the vast differences between the Dutch and the US legal systems and legal cultures, it is not really possible to make a true comparison between the US legal concepts of discovery and disclosure of evidence on the one hand and the Dutch civil procedural regime

68. See, for instance: HR 24 maart 1995, NJ 1998, 414

69. HR 8 June 2012, LJN BV8510 (Abu Dhabi Islamic Bank/ABN Amro N.V.). In this case, the Dutch Supreme Court overturned a decision by the Amsterdam Court of Appeals in which the appeals court dismissed a separate claim for disclosure of documents on the basis of Art. 843a DCCP on the basis that the main proceedings of the case were pending abroad, not in the Netherlands. The Supreme Court made clear that it is indeed possible under Art. 843a DCCP to file a separate claim for disclosure of documents in relation to a case that has not been and is not likely to be initiated before a Dutch court. This ruling by the Dutch Supreme Court can be particularly relevant in the context of foreign direct liability cases where it comes to gaining access to documents in the possession of a Dutch branch of a multinational corporations that is being sued elsewhere.

70. See, for instance: De Bock 2011, pp. 139-142; Sijmonsma 2010, pp. 80, 225-227.

71. Van Den Reek, for instance, in 1997 still spoke of Art. 843a DCCP as a 'little known but nevertheless remarkably powerful procedural disclosure obligation': Van Den Reek 1997, p. 46. 
on the production of exhibits on the other. ${ }^{72}$ As a result, the extent to which the US legal system may serve as an example, a touchstone, or a source of inspiration in this context is necessarily limited. Nevertheless, a brief foray into the US rules on discovery and disclosure will be included here, as it offers a frame of reference that may help us to better understand (the restrictions inherent in) the Dutch civil procedural regime on the production of exhibits. ${ }^{73}$

In the US legal system, civil litigation is an accepted means through which not only private rights but also public regulations and policies can be privately enforced. A long-prevalent legal culture of what has been termed 'adversarial legalism' has, it is said, resulted in a legal system that is unique when it comes to its openness to "[...] new kinds of justice claims and political movements," and as regards the flexibility and creativeness of its courts. ${ }^{74} \mathrm{~A}$ tradition of public interest and impact litigation, in the sense that civil litigation has long been used as a way to promote societal change, has shaped the general idea that civil litigation may serve broader, more prospective aims. This particular legal culture is supported by socio-legal structures enabling this role for civil litigation, including, among other things, a system of civil litigation that, due to a unique combination of legal, procedural and practical features, is generally considered to be highly plaintiff-friendly. ${ }^{75}$ One of the features that makes the US civil litigation culture such a plaintiff-friendly one is the fact that it has a low threshold for initiating civil claims and broad possibilities for plaintiffs to subsequently obtain evidence from others in order to substantiate those claims. The US rules on pre-trial discovery are generally considered to be favourable to plaintiffs in civil cases, especially in combination with the fact that the initial statement of claim may be based upon mere skeleton allegations of the key facts and a reasonable belief in the allegations put forward, which need only be substantiated in a later phase of the proceedings. On the basis of these rules, defendants (and others as well) may be compelled to "[...] disclose information in their possession that might be useful as evidence to prove the plaintiffs' case,"76 enabling plaintiffs to investigate possible wrongdoing by those defendants in the course of the civil procedure itself,

72. Note that English law also has statutory provisions on the disclosure of documents, which may come into play pending a civil procedure as well as prior to such a procedure ('pre-action disclosure'). See, for further details: part 31 Civil Procedure Rules ('Disclosure and inspection of documents'), available at <hwww.justice.gov.uk/courts/procedurerules/civil/rules/part31>. In view of the limited scope of this article, a further discussion of these provisions will be left out here.

73. It should be noted that within the US legal system, rules of civil procedural law may vary between federal and state cases and also from state to state. The following discussion will be based on the US federal rules of civil procedure.

74. See, for instance: Kagan 2001, p. 3 et seq. See also Magnus 2010, who emphasizes the ability of US tort law "[...] to discover or invent innovative solutions," as well as "[...] the vivid creativity and rapid development of the US tort system" (pp. 119-120).

75. See, in more detail and with further references, for instance: Enneking 2012, pp. 191-194, 252-256.

76. Carrington 2004, p. 1416 thus allowing them to initiate such a procedure even if they do not have all the evidence necessary to prove such wrongdoing at its outset. ${ }^{77}$

Generally speaking, the US system of civil procedure is highly adversarial in nature, more so than its Dutch counterpart, meaning that the parties to a civil procedure before a US court are largely the ones to determine its scope and course and are also the ones responsible for the furnishing of proof. The court's role is in principle a passive one; only by way of exception, for instance in civil procedures that strongly impact on public interests like those involving the role and functioning of public institutions or in civil procedures that involve large numbers of plaintiffs, will US courts take up a position as active case managers. ${ }^{78}$ Due to this adversarial nature and the courts' relatively passive role where it comes to the discovery of information on relevant facts and circumstances relating to the cases before them, there seems to be less of an emphasis on seeking and establishing the material truth in civil procedures before US courts than is the case in similar procedures before Dutch courts.

Civil procedures before US courts tend to be less compact than those before Dutch courts and are generally composed of two separate stages: the stage at which the oral hearing of the dispute takes place (the trial phase) and stage preceding it (the pre-trial phase). The procedure commences with the filing of a complaint by the plaintiffs and a response to that complaint by the defendants. The requirements as to the plaintiffs' obligation to furnish facts are not very stringent, meaning that it will generally be easier for plaintiffs in a civil procedure before a US court to meet those requirements than it is for plaintiffs in a civil procedure before a Dutch court. ${ }^{79}$ Furthermore, any company that is involved in a civil procedure before a US court is supposed to at the outset of the procedure file a disclosure statement in which its parent company or parent companies (if applicable) are identified, as well as any companies that are quoted on the stock exchange and hold more than 10 percent of its shares. The objective of this provision is not to create transparency for the benefit of the procedure itself, but rather to provide the judge(s)

77. See, for instance, with further references: Magnus 2010, pp. 116-117. See also, with a focus on domestic legal remedies for international human rights violations: Stephens 2002, pp. 15-16.

78. See, for instance, Oakley \& Amar 2009, pp. 26-27. See, for a more detailed discussion of the nature of US civil procedural law and its consequences for the system of evidence gathering, in a comparative perspective: Verkerk 2010.

79. See, Rule 8(a) of the Federal rules of civil procedure (hereinafter: FRCP), according to which the claim merely needs to contain " $[\ldots]$ a short and plain statement of the claim showing that the pleader is entitled to relief." Available at: <www.law.cornell.edu/rules/frcp/>. Rule 11(b) FRCP further determines that the plaintiffs or their attorney are to declare when filing the claim that "[...]to the best of the person's knowledge, information, and belief, formed after an inquiry reasonable under the circumstances", "(3) the factual contentions have evidentiary support or, if specifically so identified, will likely have evidentiary support after a reasonable opportunity for further investigation or discovery." See also, Ekelmans 2010, p. 33 and, for a more detailed discussion, Oakley \& Amar 2009, pp. 164-171. 
involved with an indication of whether a conflict of (financial) interests exists that should lead them to recuse themselves. ${ }^{80}$ Nonetheless, it does, as a side effect, offer the opposing party to the procedure a certain measure of insight into the companies that have a financial interest in the company involved.

After these initial documents have been filed and any preliminary motions raised in response to the complaint have been dealt with by the court, ${ }^{81}$ the dispute will proceed to the phase of pre-trial discovery, which is largely shaped by the parties themselves. ${ }^{82}$ Based on the idea of enabling a fair contest between the parties to a civil dispute, which is particularly important in view of the adversarial nature of civil procedures before US courts and the accompanying passive role of those courts, US rules on the gathering of evidence generally give broad possibilities for the inspection of documents that are in the possession of the opposing side or of third parties. ${ }^{83}$ The standard laid down in the Federal Rules of Civil Procedure in this respect is that the parties may "[...] obtain discovery of any non-privileged matter that is relevant to any party's claim or defense"; whether the information requested is in fact admissible at the trial or not is irrelevant, as long as "[...] the discovery appears reasonably calculated to lead to the discovery of admissible evidence". ${ }^{84}$ The frequency and extent of discovery is statutorily limited, but may be limited further by the court, for instance where the court finds that the information sought can more conveniently, less burdensomely or less expensively be obtained from another source or that the burden or expense of obtaining the information requested through discovery outweighs its likely benefit. ${ }^{85}$

In response to criticism that the discovery procedure, also because of its strong orientation towards party autonomy, has the potential to dominate civil procedures and involve disproportionate costs for both the parties involved in a dispute and the US legal system as a whole, the procedure has over the past few decades been amended in a number of ways. One of the most important amendments has been the introduction of an obligation of initial disclosures, under which each party at the outset of the pre-trial discovery phase must of his own accord provide the other party with data on a number of specific issues. These include, among other

80. Rule 7.1 FRCP.

81. Those may include, for example, motions relating to lack of personal jurisdiction, lack of subject matter jurisdiction, improper venue, or failure to state a claim upon which relief can be granted; Rule 12(b) FRCP.

82. See, for instance: Oakley \& Amar 2009, p. 176.

83. See, for instance: Oakley \& Amar 2009, p. 171. Note that these rules may vary between federal and state cases and also from state to state (see also note 73).

84. Rule 26(b)(1) FRCP. See also, for instance: Oakley \& Amar 2009 pp. 171-173. Privileged information includes, among other things, confidential communications between the party and its attorney, between spouses and between doctor and patient. See, in more detail, for instance: Oakley \& Amar 2009, pp. 228-233.

85. Factors to be taken into account in determining whether the burdens/ expenses outweigh the benefits include "[...] the needs of the case, the amount in controversy, the parties' resources, the importance of the issues at stake in the action, and the importance of the discovery in resolving the issues"; Rule 26(a)(2)(C) FRCP. things, the details of individuals likely to have discoverable information that the disclosing party may use to support its claims or defences and the subjects of that information, copies of the items of evidence that are in the possession of the disclosing party and that it may seek to rely on to support its claims of defences, and computations of the different categories of damages claimed by the disclosing party, including the data on which these computations are based, such as materials relating to the nature and extent of injuries suffered. ${ }^{86}$ The information obtained through this round of initial disclosures is supposed to enable the parties to the dispute to use the broad possibilities offered by the discovery procedure in a more targeted way. ${ }^{87}$

\section{Impediments to Transparency in Dutch Foreign Direct Liability Cases}

The relatively liberal regime on pre-trial discovery in civil procedures before US courts has tended to play an important role in US foreign direct liability cases, especially in view of the lack of transparency that typically exists in these cases not only with respect to the group and organizational structures of the multinationals involved, but also with respect to the detrimental effects of their transnational activities on people and planet elsewhere.

An example is the Unocal-case, which revolved around civil claims brought before a US federal court against US-based multinational oil company Unocal in relation to allegations of its involvement in human rights violations perpetrated by the Birmese military regime in the course of the construction of a local gas pipeline project jointly run by Unocal and a number of other corporate actors, including Total. ${ }^{88}$ In this case, the evidence gathered included, among many other things, a communication by Total to Unocal that could have turned out to be crucial evidence as to Unocal's alleged awareness of the human rights violations perpetrated by the Birmese military in furtherance of the project - if the case had proceeded to trial instead of being settled out of court, as it was. The communication stated:

[...] About forced labour used by the troops assigned to provide security on our pipeline project, let us admit between Unocal and Total that we might be in a grey zone.
86. Rule 26(a)(1) FRCP. See also, for instance: Oakley \& Amar 2009, pp. 175-176. In addition, each party is supposed to disclose the identity of the experts that it may use at trial to present evidence, along with a statement of the opinion each expert witness will express and the basis and reasons for those opinions: Rule 26(a)(2) FRCP.

87. See, for instance: Oakley \& Amar 2009, p. 176.

88. See, for details and further references: Enneking 2012, pp. 96-98. 
However, despite the obvious advantages that it may entail for plaintiffs in civil procedures in general and in foreign direct liability cases more specifically, it must be noted that the US system of pre-trial discovery is also prone to abuse, as it may be used strategically by those involved in a legal dispute to drive up the costs, to wear out the opposing party and/or to force favourable settlements. ${ }^{89}$ It is for this reason that across the Atlantic, this system, also in forming part of the plaintiff-friendly US litigation culture, is often depicted as being excessive and something to be avoided rather than welcomed. Disadvantages that are commonly perceived with the US litigation culture include over-precaution, which may lead to high costs for potential tortfeasors; deterrence of economically valuable activities and restraints on innovation; abuse of civil procedures for unmeritorious claims, which may lead to high societal costs and socalled 'blackmail settlements'; insurance issues; and high transaction costs. ${ }^{90}$

Also in the Netherlands, both the US litigation culture in general and the US system of pre-trial discovery more specifically are looked upon with suspicion, as they seem to engender an almost unreasonable fear of a US-style 'claim culture'. ${ }^{91}$ This may also (at least partly) explain the fact that a recent and still ongoing attempt at revising the Dutch civil procedural regime on the production of exhibits as laid down in Article 843a DCCP has so far yielded few real results. The background to this attempt was a suggestion, made within the scope of a broader project involving the revision of the Dutch system of civil procedure, to introduce an obligation of disclosure of documents similar to the one that exists in English law. ${ }^{92}$ In turn, this suggestion was made in response to a demand by Dutch legal practitioners for a legal remedy that would make it possible to compel the opposing party in a civil lawsuit at an early (or earlier) stage in the proceedings to provide insight into the evidentiary materials that it possesses. ${ }^{93}$ In response to this suggestion, a proposal was drafted for a new, more liberal regime on the production of exhibits in civil procedures, which resulted in the introduction in late 2011 of a bill aimed at improving the current statutory regime. In this bill, however, many of the proposed changes have been watered down, meaning that the proposed changes amount to little more than a codification of existing case law and as such do not involve a substantial liberalization and/or alteration of the regime as it was. ${ }^{94}$ Most importantly, the substantive requirements that need to be satisfied in order for the court to grant a request for disclosure of documents on the basis of Article 843a DCCP (legitimate interest, adequate specifica-

89. See, for instance: Oakley \& Amar 2009, p. 171.

90. Compare, for instance: Kortmann 2009.

91. See, in more detail and with further references: Enneking 2012, pp. 252-256.

92. See Asser et al. 2006, pp. 71-75.

93. Asser et al. 2006, p. 72.

94. Kamerstukken I/ 2011/12, 33 079. See, for a detailed discussion Ekelmans 2012. See also, on an earlier version of the bill that was introduced in 2010: Ekelmans 2011. tion, existing legal relationship) have by and large remained the same in the proposed new regime on the production of exhibits in civil procedures (Articles 162a-162c DCCP). This has raised questions among NGOs and even among some politicians, since the current regime is perceived to constitute a significant threshold for plaintiffs who seek to bring foreign direct liability claims before Dutch courts. In combination with the inequality of arms between the host country plaintiffs on the one hand and the corporate defendants on the other that typically exists in these cases where it comes to financial scope, level of organization and access to relevant information, this threshold is likely to seriously diminish their chances of successfully bringing such claims before Dutch courts.

The September 2011 Decision by the The Hague district court in the Dutch Shell case shows that a restrictive interpretation of the rule on document disclosure as provided by Article 843a DCCP may indeed result in a 'catch-22' situation for plaintiffs in foreign direct liability cases. The main reason for the court to dismiss the plaintiffs' requests for disclosure of certain documents by both parent company RDS and its Nigerian subsidiary SPDC was that according to the court the plaintiffs lacked a legitimate interest in disclosure of the requested documents. ${ }^{95}$ With respect to the requests by the plaintiffs for disclosure of documents relating to the maintenance of the pipelines from which the oil spills had occurred, documents that they sought to use in order to prove that the oil spills in dispute were a result of faulty maintenance and not of sabotage, as was claimed by Shell, the court considered, inter alia,

The legitimate interest in production of exhibits is [...] limited to those items of evidence that may contribute to the substantiation/demonstration of possibly decisive arguments, which are sufficiently concretely substantiated and disputed. In view of this, [plaintiffs] have as yet failed to contest Shell et al.'s argument that this leakage was caused by sabotage in a sufficiently reasoned manner, so that this argument, at the present stage of the debate, must provisionally be considered correct. This leads to the conclusion that [plaintiffs] presently have no legitimate interest in items of evidence that shed light on the situation concerning the pipeline in question and its maintenance. ${ }^{96}$

95. Rechtbank 's-Gravenhage, 14 September 2011, LJN BU3529 (oil spill near Ikot Ada Udo); LJN BU3535 (oil spill near Oruma); LJN BU3538 (oil spill near Goi). See, for the English version of these decisions the Milieudefensie website: <http://www.milieudefensie.nl/english/shell/ oil-leaks/courtcase/press/documents/documents-on-the-shell-legalcase\#legal>. It should be noted that the court in the case pertaining to the oil spill near Goi did grant one request with respect to reports that had been drafted by SPDC subcontractors with respect to the sanitation activities that had been undertaken in the wake of the oil spills involved in that case, as the plaintiffs' request with respect to these particular documents had not been contested by Shell.

96. See, for instance: Rechtbank 's-Gravenhage, 14 September 2011, LJN BU3535 (oil spill near Oruma), paras. 4.9-4.10. 
A similar argumentation led the court to dismiss the plaintiffs' requests for disclosure of documents relating to the environmental policies within the multinational Shell group and the command structure between the Dutch parent company and its Nigerian subsidiary. According to the court, the plaintiffs had failed to sufficiently substantiate their claims that under Nigerian tort law there could be liability on the part of the parent company and/or its subsidiary for the damage resulting from the oil spills in dispute. ${ }^{97}$ This opinion of the court was connected to the fact that in their writ of summons claims, the plaintiffs had based their claims against both corporations on Dutch tort law, whereas the court, in the same judgment as the one in which it dismissed the plaintiffs' request for disclosure of documents, identified Nigerian tort law as the applicable law governing the case. ${ }^{98}$

Finally, the court in the same judgment also dismissed the plaintiffs' appeal to the equality of arms principle, which ensues from the right to a fair trial as laid down in Article 6 ECHR. It considered that Article 843a DCCP is based on that very principle and that any of the statutory limitations imposed on the right to request disclosure of documents as laid down in that Article are in principle compatible with Article 6 ECHR and the equality of arms principle, except where special circumstances dictate otherwise. According to the court, the plaintiffs in the Dutch Shell Nigeria case had failed to prove the existence of such special circumstances under which a deviation from the regular interpretation of Article 843a DCCP and its inherent restrictions was warranted..$^{99}$ All in all, the The Hague district court's September 2011 decision does seem to indicate that the relatively restrictive Dutch regime on the production of exhibits in civil procedures may potentially impose a structural barrier on the access to remedies before Dutch courts of the victims of corporate violations of people and planet abroad.

\section{The Way Forward?}

Where should we look in order to find solutions to this potentially structural transparency barrier in foreign direct liability cases brought before Dutch courts?

The most obvious solution would be to seize upon the review of the DCCP that is currently ongoing in an attempt to realize a more liberal statutory regime on the production of exhibits in civil procedures before Dutch courts. This would also correspond with the aforementioned obligation for states under the UN 'Protect, Respect, and Remedy' policy framework on business and human rights to provide victims of corporate

97. See, for instance: Rechtbank 's-Gravenhage, 14 September 2011, LJN BU3535 (oil spill near Oruma), paras. 4.13-4.15.

98. See, for instance: Rechtbank 's-Gravenhage, 14 September 2011, LJN BU3535 (oil spill near Oruma), para. 4.3.

99. See, for instance: Rechtbank 's-Gravenhage, 14 September 2011, LJN BU3535 (oil spill near Oruma), para. 4.16. human rights abuse with access to domestic judicial mechanisms, and the accompanying call upon states by the Framework's Guiding Principles to reduce legal, practical and other relevant barriers that could lead to a denial of access to remedy in this respect. ${ }^{100}$ And indeed, attempts have recently been made to convince the Dutch government to consider a liberalization of the Dutch regime on document disclosure in view of the barriers it may raise for plaintiffs in future foreign direct liability cases, including a proposal for a parliamentary resolution to this effect. ${ }^{101}$ These attempts have, however, so far yielded limited results, largely due to a lack of political support among the current coalition parties. ${ }^{102}$ Although the Dutch government is yet to announce where its priorities will lie in implementing the Ruggie framework and accompanying Guiding Principles, it seems that those striving for a liberalization of the Dutch statutory regime on the production of exhibits in view of the barriers it poses to plaintiffs in foreign direct liability cases face an uphill battle. Both the current provision and the proposed new one are, like most of the provisions in the DCCP, generic in nature in the sense that they apply to any kind of civil procedure that is brought before a Dutch court. Also in view of the limited role that foreign direct liability cases play at this point within the broader framework of all the different types of civil procedures that are brought before Dutch courts on (for example) an annual basis, it seems unlikely that the Dutch Ministry of Justice, which is in charge of the current review of the DCCP, will be easily swayed to introduce a special clause or a special exception in the Code that specifically pertains to foreign direct liability cases.

One of the avenues that might prove to be more promising, at least where calls for legislative action are concerned, would be to strive for a legally enshrined duty for Netherlands-based multinationals to draw up and disclose due diligence reports on the detrimental impacts that their activities as well as those of their foreign subsidiaries or business partners may have or are having on people and planet abroad. This would link up with the recommendations made in this respect by the UN policy framework on business and human rights and accompanying Guiding Principles, as well as with calls by NGOs such as SOMO and Amnesty for more stringent statutory requirements for Netherlands-based multinationals to disclose non-financial information. The enhanced transparency with respect to the CSRperformance of Netherlands-based multinationals abroad that this would engender would be highly valuable for those seeking to address issues in this respect not only in general but also in the specific context of foreign direct liability cases. It could be further strengthened by adding to it an accompanying legal duty to produce such reports, also those not made public, in case issues arise with respect to the way any of these multinationals deal

100. Guiding Principles, principle 26.

101. Kamerstukken I/ 2012/13, 26485, No. 153.

102. Handelingen TK 2012/2013, 26485, No. 69. 
with their responsibilities for people and planet abroad in this transnational context (comparable for instance to the legal obligation for employers to produce certain documents in wage disputes with their employees that is laid down in Article 7:619 of the Dutch Civil Code).

In view of the fact that legislative action requires political support, support that may be hard to come by in the current political and economic climate in the Netherlands, those seeking to address and/or get round the transparency barrier posed in foreign direct liability cases brought before Dutch courts by the relatively restrictive Dutch regime on document disclosure should also seek to pursue other avenues that do not require legislative action. This may require a further exploration of the regime's boundaries, in future foreign direct liability cases, and the way it interacts with substantive (as opposed to procedural) legal rules on the burden of proof in civil cases. This should also include attempts to file pre-trial requests for document disclosure. After all, if granted such requests could prove instrumental not only in giving the host country plaintiffs a better idea of their position and of the feasibility of their claims, but also in determining which legal entity or entities within the corporate group their claims should be directed at.

A further exploration of the role that the Dutch civil procedural regime on document disclosure should help to provide some answers to the question whether the regime does indeed pose a structural barrier to plaintiffs in foreign direct liability cases. Will other courts reach similar decisions in the Dutch Shell Nigeria case and/or in similar cases, regardless of the particular circumstances of each case? Both parties in the Dutch Shell Nigeria case have filed appeals against the The Hague district court's decision. It will be interesting to see how the The Hague Court of Appeals will deal with a renewed request that was filed in September 2013 by the plaintiffs in this case for Shell to provide exhibits of evidentiary documents pertaining to the condition of the oil pipelines involved and the Shell group's internal policies and operational practices.

If it were to turn out that the Dutch regime on document disclosure may indeed pose structural barriers in this type of litigation, this raises the question whether the inherent inequality of arms in these cases constitutes a violation of Article 6 of the European Convention on Human Rights. This question may be raised in future foreign direct liability cases before Dutch courts or, if necessary, even before the ECHR. At the same time, Dutch policymakers should in that case be reminded of and made to act on their obligation under the Ruggie framework to reduce legal and practical barriers leading to a denial of access to remedy for victims of corporate human rights abuses. Another possibility would be to use this information to try and convince courts in future foreign direct liability cases to impose a strengthened obligation on the corporate defendants involved to furnish relevant facts or even a reversal of the burden of proof.

Together, these actions should go at least some way in mitigating the transparency barrier that seems to exist in
Dutch foreign direct liability cases due to the limitations posed by the Dutch civil procedural regime on document disclosure. In turn, this will further strengthen the role that these foreign direct liability cases, and the field of tort law more generally, may play in promoting corporate accountability in relation to the detrimental impacts that the transnational activities of Netherlandsbased multinationals may have on people and planet abroad.

\section{Bibliography}

W.D.H. Asser et al., Uitgebalanceerd - Eindrapport Fundamentele herbezinning Nederlands burgerlijk procesrecht, The Hague, Ministerie van Justitie, 2006.

P.D. Carrington, "The American Tradition of Private Law Enforcement", 5 German Law Fournal, 2004, p. 1413.

R.H. De Bock, Tussen Waarheid en Onzekerheid: Over het Vaststellen van Feiten in de Civiele Procedure, Deventer, Kluwer, 2011.

J.C. Drimmer \& S.R. Lamoree, "Think Globally, Sue Locally: Trends and Out-of-Court Tactics in Transitional Tort Actions", 29 Berkeley Fournal of International Law, 2011, p. 456.

J. Ekelmans, De Exhibitieplicht, Deventer, Kluwer, 2010.

J. Ekelmans, "Het wetsvoorstel over het recht op inzage, afschrift of uittreksel van bescheiden - Geen eindspel, maar een tussenstand", 60 Ars Aequi, May 2011, p. 346.

J. Ekelmans, "Het inzagerecht verbeterd?", 29 Nederlands Tijdschrift voor Burgerlijk Recht, 2012, p. 49.

L.F.H. Enneking, Foreign Direct Liability and Beyond - Exploring the Role of Tort Lam in Promoting International Corporate Social Responsibility and Accountability, The Hague, Eleven International Publishing, 2012.

L.F.H. Enneking, "The Future of Foreign Direct liability? Exploring the International Relevance of the Dutch Shell Nigeria-case", Utrecht Law Reviem, forthcoming 2014.

I. Giesen, Bewijs en aansprakelijkheid, Den Haag, Boom Juridische uitgevers, 2001.

R. Kagan, Adversarial Legalism: The American Way of Law, Cambridge, MA, Harvard University Press, 2001.

M. Kerr et al., Corporate Social responsibility - A Legal Analysis, Markham, Ontario, LexisNexis, 2009.

J. Kortmann, The Tort Law Industry, Amsterdam, Amsterdam University Press, 2009.

T.E. Lambooy, Corporate Social Responsibility - Legal and SemiLegal Framemorks Supporting CSR, The Hague, Kluwer, 2010.

M.A. Loth et al., Waarheid en waarheidsvinding in het recht, Deventer, Kluwer, 2012.

A. Maes, "A European Sister Judgment for Kiobel?", (12 June 2013). Available at: <http://conflictoflaws.net/2013/a-european-sister-judgment-for-kiobel-2/ $>$.

U. Magnus, "Why Is US Tort Law So Different?”, 1 fournal of European Tort Lam, 2010, p. 102.

J.B. Oakley \& V.D. Amar, American Civil Procedure: A Guide to Civil Adjudication in US Courts, Alphen aan den Rijn, Kluwer Law International, 2009.

J.R. Sijmonsma, Het inzagerecht, Deventer, Kluwer, 2010.

H.J. Snijders et al., Nederlands Burgerlijk Procesrecht, 4th edn., Deventer, Kluwer, 2007.W.A.J.P. Van Den Reek, Mededelingsplichten in het Burgerlijk Procesrecht, Deventer, Tjeenk Willink, 1997.

B. Stephens, "Translating Filártiga: A Comparative and International Law Analysis of Domestic Remedies for International 
Human Rights Violations”, 27 Yale Fournal of International Law, 2002, p. 1.

R. Verkerk, Fact-Finding in Civil Litigation - A Comparative Perspective, Antwerp, Intersentia, 2010.

L. Wijnbergen, "Informatieplichten in het burgerlijk procesrecht en de geraden geachte gevolgtrekking", 142 Weekblad voor Privaatrecht, Notariaat en Registratie, 2011, p. 974. 